\title{
PEMBUATAN GEL EKSTRAK DAUN PETAI CINA (Leucaena glauca, Benth) DENGAN BASIS GEL LIDAH (Aloe Vera L.) BUAYA SEBAGAI OBAT LUKA TERBUKA
}

\author{
Elvira Dita Kurnia1, Dewi Ratnasari ${ }^{2 *}$, Yusi Helmiawati ${ }^{3}$ \\ 1,2,3Sekolah Tinggi Ilmu Kesehatan Holistik \\ *Korespondensi: Jl. Veteran No. 272 Ciseureuh Purwakarta, Email: dewiratnasari@stikesholistic.ac.id
}

\begin{abstract}
ABSTRAK
Latar Belakang: Petai Cina (Leucaena glauca, Benth) merupakan tanaman yang biasa digunakan masyarakat Cikampek sebagai obat luka tradisional. Penggunaannya secara tradisional dipilih karena tidak memiliki efek samping mengiritasi kulit. Tetapi, pada penggunannya tidak praktis dan tidak dapat disimpan lama, sehingga perlu adanya inovasi sediaan yang praktis dan awet pada penyimpanannya.

Tujuan: Penelitian ini bertujuan untuk mengetahui cara pembuatan sediaan gel dari esktrak daun petai cina (Leucaena glauca, Benth) dengan basis gel lidah buaya (Aloe Vera L.), dan untuk mengetahui stabilitas penyimpanan pada suhu kamar.

Metode: Metode penelitian ini menggunakan penelitian tindakan dengan instrumen penelitian berupa studi pustaka dan lembar pengamatan. Sediaan dibuat dua sampel dengan komposisi yang sama yaitu ekstrak daun petai cina (Leucaena glauca, Benth) 15 gr dan gel lidah buaya (Aloe Vera L.) 50 gr.

Hasil: Rata-rata persentase hasil susut pengeringan simplisia daun petai cina (Leucaena glauca, Benth) sebesar 2,46\%, ekstrak daun petai cina (Leucaena glauca, Benth) positif mengandung saponin, berdasarkan uji stabilitas $\mathrm{pH}$ mengalami penurunan pada penyimpanan, daya sebar gel yang didapat memenuhi kriteria yaitu $5 \mathrm{~cm}$, sediaan homogen, dan bertahan selama 18 hari..

Kata kunci: Gel ekstrak daun petai cina, Lidah buaya sebagai basis gel, Luka
\end{abstract}

\section{ABSTRACT}

Background: Chinese Petai (Leucaena glauca, Benth) is a plant commonly used by the Cikampek community as a traditional wound medicine. Its use is traditionally chosen because it has no side effects to irritate the skin. However, it is impractical and cannot be stored for a long time, so there is a need for innovative, practical and durable preparations for storage.

Objective: This study aims to determine how to make gel preparations from leaf extractsChinese petai leaf (Leucaena glauca, Benth) with base of Aloe Vera gel (Aloe Vera L.), and to know the stability of storage at room temperature.

Method: This research method uses action research with research instruments in the form of literature studies and observation sheets. Two samples were prepared with the same composition, namely Chinese petai leaf extract (Leucaena glauca, Benth) $15 \mathrm{~g}$ and Aloe Vera L. $50 \mathrm{~g}$.

Results: The average percentage of yield shrinkage of Chinese petai leaf simplicia (Leucaena glauca, Benth) was 2,46\%, Chinese petai leaf extract (Leucaena glauca, Benth) positively contained saponin based on the $\mathrm{pH}$ stability test decreased in storage, the gel dispersion obtained obtained met the criteria of $5 \mathrm{~cm}$, homogeneous preparations, and last for 18 days.

Key words: Chinese petai leaf extract gel, Aloe vera as a base gel, Wound

\section{PENDAHULUAN}

Penggunaan obat luar yang mengandung Povidon iodine sangat lumrah digunakan oleh masyarakat, tetapi efek samping yang timbul yaitu mengiritasi kulit. Manusia telah lama mengenal fungsi tumbuhan sebagai penghasil obat-obatan, karena secara turun menurun pengetahuan itu dipertahankan dengan penuturan secara lisan.[1] Tingginya harga obat sintesis dan adanya efek samping yang merugikan kesehatan memicu masyarakat untuk menggunakan obat tradisional.[2] Sehingga sebagian masyarakat lebih memilih obat dari bahan alami karena tidak mengiritasi kulit.

Di Indonesia terdapat berbagai macam tanaman yang dapat digunakan 
sebagai obat tradisional luka terbuka diantaranya yaitu tanaman kecombrang (Etlingera elatior), tanaman binahong (Anredera Cordifolia), tanaman talas (Colocasia esculenta L) dan tanaman petai cina (Leucaena glauca, Benth). Peneliti memilih tanaman petai cina sebagai bahan dari penelitiannya karena tanaman ini banyak tumbuh di perumahan, di kebun, maupun tumbuh liar di jalan umum daerah Cikampek, karena ketersediaannya yang berlimpah dan mudah ditemui, peneliti memanfaatkan tanaman petai cina sebagai obat tradisional luka terbuka yang akan dikembangkan dalam bentuk sediaan gel.

Terdapat berbagai macam kegunaan petai cina dalam kehidupan sehari-hari diantaranya daunnya bisa digunakan untuk mengobati luka baru dan bengkak dengan cara daunnya dikunyah atau digerus lalu ditempelkan pada luka.[3] Daun petai cina mengandung zat aktif berupa alkaloid, saponin, flavonoid, mimosin, lektin, lemak, kalsium, fosfor, zat besi, vitamin A dan vitamin B. Kandungan yang berperan sebagai anti inflamasi adalah saponin sehingga dapat mempercepat peryembuhan luka. Antibiotik yang terdapat dalam saponin berperan sebagai penghambat pertumbuhan bakteri sehingga proses penyembuhan luka akan semakin cepat, sementara lektin berperan untuk menstimulasi pertumbuhan sel kulit baru.[4]

Selain itu tanaman lain yang dapat digunakan sebagai obat tradisional penyembuhan luka terbuka yaitu lidah buaya. Lidah buaya mempunyai khasiat sebagai obat luka. Daun lidah buaya mengandung saponin, flavonoid, tanin dan polifenol.[5] Getah lidah buaya mengandung polisakarida yang dapat mempercepat penyembuhan luka dan mengurangi reaksi peradangan. Saponin yang terkandung dalam lidah buaya berkhasiat untuk membunuh kuman. Gel lidah buaya mengandung lignin yang mampu menembus dan meresap ke dalam kulit. Gel ini akan menahan hilangnya cairan tubuh dalam permukaan kulit sehingga kulit tidak mengalami kekeringan.[6]
Berdasarkan penelitian yang telah dilakukan sebelumnya bahwa kebiasaan masyarakat menggunakan daun petai cina sebagai obat luka alami serta banyaknya tumbuhan petai cina dan tumbuhan lidah buaya yang tumbuh di lingkungan masyarakat sehingga bahan yang didapat sangat mudah ditemui, maka dari itu peneliti tertarik untuk mengembangkan sediaan daun petai cina dalam bentuk gel dengan basis gel yang alami yaitu dari tanaman lidah buaya (Aloe Vera L.) karena peneliti menerapkan konsep holistik pada pembuatan dan pemilihan bahannya sehingga tidak ada campuran bahan kimia lainnya. Gel lidah buaya terdiri dari jaringan parenkim yang mengadung gel muchilago (bahan pengikat) yang berfungsi sebagai pengikat bahan pada proses pembuatan gel sehingga lidah buaya dapat dijadikan sebagai gelling agent alami pada pembuatan sediaan gel ekstrak daun petai cina (Leucaena glauca, Benth) sebagai obat luka terbuka.

Tujuan penelitian ini yaitu membuat sediaan dari ekstrak daun petai cina yang dikombinasikan dengan gel lidah buaya, yang dapat menyembuhkan luka terbuka dan memberikan efek mendinginkan pada peradangan (inflamasi). Serta mengetahui cara pembuatan sediaan gel dari esktrak daun petai cina (Leucaena glauca, Benth) dengan basis gel lidah buaya (Aloe Vera L.), dan untuk mengetahui stabilitas penyimpanannya pada suhu kamar. Selain dilakukan pengujian susut pengeringan, uji fitokimia, uji $\mathrm{pH}$, uji homogenitas, uji daya sebar dan pengamatan organoleptis. Pengamatan dilakukan dalam setiap hari dalam waktu tiga minggu pada penyimpanan suhu kamar.

\section{METODE PENELITIAN}

Penelitian ini dilaksanakan pada bulan Juni - agustus 2019, selama tiga bulan di Laboratorium Sekolah Tinggi Ilmu Kesehatan Holistik Purwakarta yang beralamat di Jalan Veteran No. 272 Ciseureuh (Kebon Kolot) Purwakarta. Metode penelitian yang digunakan adalah penelitian tindakan (action research). 


\section{ALAT DAN BAHAN}

Alat yang digunakan dalam penelitian ini adalah blender, beaker glass, tabung reaksi, mortir dan stamfer, cawan penguap, kaca arloji, desikator, oven, saringan, timbangan digital, sudip, spatula logam, panci, baskom. Dan bahan yang digunakan dalam pembuatan gel adalah ekstrak daun petai cina (Leucaena glauca, Benth) yang tumbuh di daerah cikampek dan lidah buaya (Aloe Vera L.) yang ditanam dihalaman rumah daerah Cikampek.

\section{CARA KERJA}

\section{Pengumpulan Sampel Daun Petai cina}

Sampel daun petai cina didapatkan dari tanaman petai cina yang tumbuh di daerah Cikampek. Daun yang dipetik dipisahkan dari tangkainya dan dicuci bersih terlebih dengan air mengalir.

\section{Pengeringan Sampel Daun Petai Cina}

Pengeringan daun petai cina dilakukan dengan cara dikeringkan dibawah sinar matahari selama 2 hari sampai kadar air pada sampel kurang dari 10\%. Lalu dilakukan perhitungan susut pengeringan, yaitu dengan cara : Siapkan 3 cawan petri, timbang kemudian catat hasilnya, masukkan 5 gram simplisia ke dalam cawan, dan oven cawan berisi simplisia pada suhu $105^{\circ} \mathrm{C}$ selama 1 jam. Setelah 1 jam, tiriskan cawan menggunakan desikator selama 30 menit. Jika sudah 30 menit, timbang cawan dan catat hasilnya. Dan hitung susut pengeringannyanya.

\section{Proses Ekstraksi Daun Petai Cina}

Pembuatan ekstrak daun petai cina menggunakan proses maserasi. Maserasi digunakan karena proses pengerjaan dan peralatan yang digunakan lebih sederhana. Prosedur maserasi daun petai cina yaitu: Simplisia daun petai cina diblender hingga halus, timbang serbuk simplisia daun petai cina sebanyak 100 gr. Masukkan serbuk simplisia ke dalam beaker glass. Kemudian dilakukan perendaman dengan etanol $70 \%$ sampai simplisia terendam.[7] Tutup beaker glass dengan plastik yang telah diberi lubang. Lalu dilakukan pengadukan dalam 1 x 24 jam selama tiga hari berturut-turut. Lakukan penyaringan hingga ampas simplisia dan filtrat terpisah. kemudian filtrat yang didapat dipanaskan pada cawan penguap, dan didapatkan ekstrak kental daun petai cina. Timbang ekstrak kental daun petai cina sebanyak $15 \mathrm{gr}$.

\section{Skrining Fitokimia}

Daun petai cina mengandung saponin yang berfungsi sebagai anti inflamasi pada luka yang bekerja membunuh bakteri sehingga mempercepat proses penyembuhan luka terbuka. Untuk mengetahui saponin yang terkandung dalam suatu ekstrak dengan cara: Masukkan ekstrak pekat daun petai cina 1 $\mathrm{ml}$ ke dalam tabung reaksi. Masukkan $9 \mathrm{ml}$ aquadest ke dalam tabung reaksi yang sudah terisi esktrak pekat daun petai cina, lalu kocok kuat. Lalu amati dan catat perubahan yang terjadi.[8][9]

\section{Pembuatan Basis Gel Lidah Buaya}

Peneliti menggunakan gel lidah buaya sebagai basis gel pada pembuatan gel ekstak daun petai cina. Langkah-langkah yang dilakukan antara lain : Ambil lidah buaya segar. Kemudian potong pinggiran yang berduri. Lalu cuci bersih dengan air mengalir. Dan pisahkan kulit dan daging lidah buaya menggunakan pisau. Haluskan dengan menggunakan blender hingga tekstur menyerupai gel. Saring gel lidah buaya untuk memisahkan lendir dan gel. Timbang gel lidah buaya sebanyak 50 gr.

\section{Pembuatan Sediaan}

Berikut ini adalah langkah-langkah membuat sediaan gel ekstrak daun petai cina: Siapkan alat dan bahan dengan proporsi Lidah buaya 50 gr dan esktrak daun petai cina 15 gr. Masukkan gel lidah buaya kedalam mortir panas lalu gerus. Kemudian masukkan ekstrak daun petai cina dan gerus sampai homogen. Kemas rapi dalam wadah.

\section{Uji Kualitas}

Parameter yang diamati pada uji kulitas adalah uji $\mathrm{pH}$, uji organoleptik, uji homogenitas, uji daya sebar. Uji $\mathrm{pH}$ sediaan harus memenuhi kriteria $\mathrm{pH}$ kulit yaitu dalam interval 4,5-6,5.[10]. Uji pH dilakukan setiap hari selama tiga minggu dengan menggunakan kertas indikator $\mathrm{pH}$ universal dengan cara dicelupkan pada sediaan gel ekstrak daun petai cina, dan amati warna yang terbentuk lalu bandingkan dengan standar. 
Uji Organoleptis, pengujian ini dilakukan dengan cara mengamati warna, bau, dan bentuk dari sediaan gel ekstrak daun petai cina. Pada uji homogenitas, sediaan gel ekstrak daun petai cina dioleskan pada kaca transparan, kemudian digosok dan diraba untuk mengetahui homogenitasnya dan dilakukan pengamatan adakah gumpalan maupun butiran kasar pada gel.

Uji Daya Sebar, gel seberat $500 \mathrm{mg}$ ditimbang dan diletakkan ditengah kaca bulat berskala. Sebelumnya ditimbang dahulu kaca yang lain dan diletakkan kaca tersebut di atas gel dan dibiarkan dalam satu menit. Diameter gel yang menyebar diukur dengan mengambil panjang rata-rata diameter dari beberapa sisi. Daya sebar gel yang baik $5-7 \mathrm{~cm} \cdot{ }^{[11][12]}$

\section{HASIL PENELITIAN}

Hasil uji susut pengeringan terhadap simplisia daun petai cina (Leucaena glauca, Benth) tertera pada Tabel 1 dibawah ini:

Tabel 1 Hasil Susut Pengeringan Simplisia Daun Petai Cina (Leucaena glauca, Benth)

\begin{tabular}{|c|c|c|c|}
\hline \multirow{2}{*}{ Keterangan } & \multicolumn{3}{|c|}{ Cawan } \\
\cline { 2 - 4 } & I & II & III \\
\hline Berat cawan kosong & $49,81 \mathrm{gr}$ & $48,94 \mathrm{gr}$ & $49,84 \mathrm{gr}$ \\
\hline Berat simplisia & $5 \mathrm{gr}$ & $5 \mathrm{gr}$ & $5 \mathrm{gr}$ \\
\hline Berat cawan kosong + simplisia & $54,81 \mathrm{gr}$ & $53,94 \mathrm{gr}$ & $54,84 \mathrm{gr}$ \\
\hline Penimbangan 1 & $54,78 \mathrm{gr}$ & $53,85 \mathrm{gr}$ & $54,78 \mathrm{gr}$ \\
\hline Penimbangan 2 & $54,70 \mathrm{gr}$ & $53,80 \mathrm{gr}$ & $54,70 \mathrm{gr}$ \\
\hline Penimbangan 3 & $54,67 \mathrm{gr}$ & $53,73 \mathrm{gr}$ & $54,65 \mathrm{gr}$ \\
\hline Rata-rata setiap cawan & $1,86 \%$ & $2,93 \%$ & $2,6 \%$ \\
\hline Rata-rata keseluruhan & \multicolumn{3}{|c|}{$2,46 \%$} \\
\hline
\end{tabular}

\section{SKRINING FITOKIMIA}

Hasil pengamatan yang dilakukan setelah mengocok kuat $1 \mathrm{ml}$ ekstrak daun petai cina dan $9 \mathrm{ml}$ aquadest pada tabung reaksi terbentuk buih yang stabil.

Tabel 2 Pengamatan sampel I dan II

\begin{tabular}{|c|c|c|c|c|c|c|c|c|c|c|c|c|c|c|c|c|c|c|c|c|c|c|}
\hline \multirow{4}{*}{ Sediaan I } & Hari ke- & $\mathbf{1}$ & 2 & 3 & 4 & 5 & 6 & 7 & 8 & 9 & 10 & 11 & 12 & 13 & 14 & 15 & 16 & 17 & 18 & 19 & 20 & 21 \\
\hline & pH & 6 & 6 & 6 & 6 & 6 & 6 & 6 & 5 & 5 & 5 & 5 & 5 & 5 & 5 & 5 & 5 & 5 & 5 & 5 & 5 & 5 \\
\hline & Homogenitas & \multicolumn{21}{|c|}{ Homogen } \\
\hline & Daya Sebar & \multicolumn{21}{|c|}{ Uji daya sebar yang didapat berukuran $5 \mathrm{~cm}$. } \\
\hline \multirow{4}{*}{ Sediaan II } & Hari ke- & 1 & 2 & 3 & 4 & 5 & 6 & 7 & 8 & 9 & 10 & 11 & 12 & 13 & 14 & 15 & 16 & 17 & 18 & 19 & 20 & 21 \\
\hline & pH & 6 & 6 & 6 & 6 & 6 & 6 & 6 & 6 & 6 & 5 & 5 & 5 & 5 & 5 & 5 & 5 & 5 & 5 & 5 & 5 & 5 \\
\hline & Homogenitas & \multicolumn{21}{|c|}{ Homogen } \\
\hline & Daya Sebar & & & & & & & & & $y$ & et & & $\mathrm{di}$ & 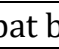 & $\mathrm{l}$ & & $\mathrm{cm}$. & & & & & \\
\hline
\end{tabular}

Tabel 3 Pengamatan Uji Organoleptis sampel I dan II

\begin{tabular}{|c|c|c|}
\hline \multirow{2}{*}{$\begin{array}{c}\text { Hari } \\
\text { ke- }\end{array}$} & \multicolumn{2}{|c|}{ Uji Organoleptis } \\
\hline & Sampel I & Sampel II \\
\hline 1 & \multirow{6}{*}{$\begin{array}{l}\text { Warna coklat tua, bau sangat kuat daun petai } \\
\text { cina, bentuk gel agak encer dan licin. }\end{array}$} & \multirow{6}{*}{$\begin{array}{l}\text { Warna coklat tua, bau sangat kuat daun petai cina, } \\
\text { bentuk gel agak encer dan licin. }\end{array}$} \\
\hline 2 & & \\
\hline 3 & & \\
\hline 4 & & \\
\hline 5 & & \\
\hline 6 & & \\
\hline 7 & \multirow{4}{*}{$\begin{array}{l}\text { Warna coklat tua, bau khas daun petai cina, } \\
\text { bentuk gel agak encer dan licin. }\end{array}$} & \multirow{4}{*}{$\begin{array}{c}\text { Warna coklat tua, bau khas daun petai cina, bentuk gel } \\
\text { agak encer dan licin. }\end{array}$} \\
\hline 8 & & \\
\hline 9 & & \\
\hline 10 & & \\
\hline
\end{tabular}




\begin{tabular}{|c|c|c|}
\hline 11 & & \\
\hline 12 & & \\
\hline 13 & \multirow{2}{*}{$\begin{array}{l}\text { Warna coklat tua, bau lemah khas daun petai } \\
\text { cina, bentuk gel agak encer dan licin. }\end{array}$} & \multirow{2}{*}{$\begin{array}{l}\text { Warna coklat tua, bau lemah khas daun petai cina, } \\
\text { bentuk gel agak encer dan licin. }\end{array}$} \\
\hline 14 & & \\
\hline$\frac{15}{16}$ & \multirow{3}{*}{$\begin{array}{l}\text { Warna coklat tua, bau agak tengik, bentuk gel } \\
\text { agak encer dan licin. }\end{array}$} & \multirow{3}{*}{$\begin{array}{l}\text { Warna coklat tua, bau agak tengik, bentuk gel encer } \\
\text { dan licin, Pada hari ke-18 muncul beberapa bintik } \\
\text { berwarna putih (berjamur). }\end{array}$} \\
\hline 17 & & \\
\hline 18 & & \\
\hline 19 & \multirow{3}{*}{$\begin{array}{l}\text { Warna coklat tua, bau agak tengik, bentuk gel } \\
\text { encer dan licin. Pada hari ke- } 20 \text { muncul } \\
\text { beberapa bintik berwarna putih (berjamur). }\end{array}$} & \multirow{3}{*}{$\begin{array}{l}\text { Warna coklat tua, bau agak tengik, bentuk gel encer } \\
\text { dan licin, dan jamur yang tumbuh semakin banyak. }\end{array}$} \\
\hline 20 & & \\
\hline 21 & & \\
\hline
\end{tabular}

\section{PEMBAHASAN}

\section{Uji Susut Pengeringan}

Berdasarkan hasil pengamatan dari Tabel 1, diperoleh rata-rata persentase hasil susut pengeringan sebesar 2,46\%, dimana hasil susut pengeringan dinyatakan memenuhi persyaratan karena kadar air yang terkandung di dalam simplisia kurang dari $10 \% .{ }^{[13]}$

\section{Uji Fitokimia}

Hasil yang didapat dari hasil uji fitokimia menyatakan bahwa daun petai cina positif mengandung saponin. Saponin yang berfungsi sebagai anti inflamasi pada luka berperan sebagai penghancur lapisan dari lilin bakteri. Selain itu saponin dapat menghambat aktivitas enzim siklooksigenase dan interleukin sehingga dapat menghambat pembentukan prostaglandin yang dapat memperpendek fase inflamasi pada penyembuhan luka.[14]

\section{Uji Kualitas}

Kualitas yang dilakukan pada penelitian ini adalah uji stabilitas pada suhu kamar (15-30C). Pengamatan dilakukan setiap hari mulai hari ke-1 sampai hari di mana gel ditumbuhi oleh jamur. Pengamatan pada hari ke-1 adalah pengamatan sesaat setelah formula dibuat. Pengamatan terdiri dari $\mathrm{pH}$, homogenitas dan daya sebar dapat dilihat pada Tabel 2 . Hasil uji organoleptis dapat dilihat pada Tabel 3.

$\mathrm{pH}$ sediaan harus memenuhi kriteria $\mathrm{pH}$ kulit yaitu dalam interval 4,56,5 . Nilai pH tidak boleh terlalu asam karena dapat menyebabkan kulit menjadi bersisik.[10] Berdasarkan hasil uji $\mathrm{pH}$ pada sampel I dan sampel II menunjukkan bahwa rentang $\mathrm{pH}$ pada Gel Ekstrak Daun Petai Cina (Leucaena glauca, Benth) Dengan Basis
Gel Lidah Buaya (Aloe Vera L.) Sebagai Obat luka Terbuka memenuhi persyaratan yaitu 5-6. Namun, pada penyimpanan hari ke-8 sampel I mengalami penurunan nilai $\mathrm{pH}$ menjadi 5 , dan pada penyimpanan hari ke10 sampel II pun mengalami penurunan hingga $\mathrm{pH}$ turun menjadi 5. Perubahan $\mathrm{pH}$ yang terjadi tidak terlalu besar sehingga masih memenuhi persyaratan yang ditentukan.

Pada bentuk gel terjadi perubahan yang semula agak encer berubah lebih mencair pada pengamatan hari ke-19. Perubahan yang lainnya yaitu sampel I ditumbuhi jamur pada hari hari ke-20 dan sampel II ditumbuhi jamur pada hari ke 18. Gel lidah buaya yang disimpan pada suhu kamar mengalami perubahan bentuk menjadi lebih mencair, perubahan bentuk ini karena sineresis yaitu peristiwa keluarnya air dalam gel.[15][16] Perubahan lain yang terjadi pada sediaan gel adalah bau. Setelah dilakukan penyimpanan pada hari ke-7 sampel I dan sampel II mengalami perubahan pada bau sangat kuat menjadi khas daun petai cina, lalu pada hari ke-13 kedua sampel mengalami perubahan lagi manjadi bau lemah khas daun petai cina. Dan pada hari ke-16 bau gel berubah menjadi bau agak tengik, bau tengik pada gel termasuk ciri sediaan gel yang rusak.

Daya sebar gel menunjukkan kemampuan gel untuk menyebar pada lokasi pemakaian apabila dioleskan pada kulit, daya sebar gel yang baik 5-7 cm.[11][12] Pada Tabel 2 menunjukkan bahwa sampel I dan sampel II memiliki daya sebar $5 \mathrm{~cm}$ hal ini menunjukkan bahwa daya sebar yang didapat telah memnuhi persyaratan. Pada uji homogenitas didapat bahwa sediaan gel homogen, partikel kecil simplisia tersebar 
merata pada basis gel. Hal ini menunjukkan bahwa formulasi yang tercampur dengan baik.

\section{SIMPULAN}

Berdasarkan penelitian yang telah dilakukan, maka dapat disimpulkan bahwa sediaan dibuat ke dalam dua sampel dimana simplisia yang akan digunakan telah memenuhi syarat kadar air yaitu $<10 \%$, pada uji fitokimia daun petai cina positif mengandung saponin. Selain itu hasil uji pH yang didapat yaitu 6 dan 5, homogenitas pada gel pun dianggap telah memenuhi standar sediaan gel karena formulasi sediaan homogen atau merata. Serta daya sebar pada kondisi awal dan akhir sediaan sama yaitu $5 \mathrm{~cm}$. Sediaan "Pembuatan Gel Ekstrak Daun Petai Cina (Leucaena glauca, Benth) Dengan Basis Gel Lidah Buaya (Aloe Vera L.) Sebagai Obat luka Terbuka" hanya stabil dalam waktu dua minggu pada penyimpanan suhu kamar karena pada minggu ke tiga mulai ditumbuhi jamur dan berbau agak tengik.

\section{DAFTAR PUSTAKA}

1. Nurmalasari, N., Sukarsa, S., \& Hidayah, H. A. (2012). Studi kasus pemanfaatan tumbuhan sebagai obat-obatan tradisional oleh masyarakat adat kampung Naga di kabupaten Tasikmalaya, Jurnal Biosfera, 29(3) : 141-150.

2. Kuntorini, E.M. 2005. Botani ekonomi suku Zingiberaceae sebagai obat tradisional oleh masyarakat di kotamadya Banjarbaru. Bioscientiae, 2(1):25-36.

3. Ardhi. 2010. Tanaman Obat : Manfaat / Khasiat Petai Cina (Leucaena leucophala). Bandung : Sentra Informasi Iptek dan Digital Library ITB.

4. Rahmawati I. Perbedaan efek perawatan luka menggunakan gerusan daun petai cina (Laucaena glauca, benth) dan povidon iodine $10 \%$ dalam mempercepat penyembuhan luka bersih pada marmut (Cavia porcellus). Jurnal wiyata. 2014 : 1 (2): 78-92.
5. Hutapea, J. R. 1993. Inventaris Tanaman Obat Indonesia (II). Departemen Kesehatan RI Badan.

6. Latief, A. (2012). Obat Tradisional. Jakarta : Buku kedokteran EGC.

7. oight, R. 1994. Buku Pelajaran Teknologi Farmasi. Yogyakarta: Gadjah Mada University Press.

8. Ratnasari D., dan Puji R. 2018. Skiring Fitokimia dan Uji Stabilitas Sediaan Sirup Kayu Kuning (Arcangelisia flava) Untuk Memelihara Kesehatan. Ejournal.stikesholistic.ac.id.

9. Setyowati, W.A.E, dkk., 2014. Skrining Fitokimia dan Identifikasi Komponen Utama Ekstrak Metanol Kulit Durian (Durio zibenithus Murr) Verietas Petruk. Seminar nasional Kimia dan Pendidikan Kimia VI. Pemantapan Riset Kimia dan Assesmen dalam Pembelajaran Berbasis Pendekatan Saintifik. ISBN979373174-0.

10. Tranggono IR, Latifah. Buku Pegangan Ilmu Kosmetika. Jakarta : PT. Gramedia Pustaka Utama; 2007.

11. Garg A, Aggarwal D, Garg S, Sigla AK. Spreading of semisolid Formulation: an update. Pharmaceutical Tecnology. 2002; 9(2):84-102.

12. Kaur LP. Garg R. Gupta GD. Development and evalution of topical gel minoxidil from different polymer bases in aplication of alopecia. International Journal of Pharmacy and Pharmaceutical Sciences. 2010;2(3):437.

13. Indonesia, D. K. R. (2008). Farmakope Herbal Indonesia. Edisi I. Jakarta: Departemen Kesehatan RI.

14. Gohil, K.J., Patel, J.A \& Gajjar, A.K., 2010. Pharmocological Review On Centella Asiatica: A Potential Herbal Cure-all. Indian Journal of Pharmaceutical Sciences, pp.546-56.

15. Prakarsa, A. W. (2017). Pengaruh Perbedaan Tepung Labu Kuning Dalam Produk Jelly Ditinjau Dari Karakteristik Fisikokimia Dan Sensori (Doctoral dissertation, Universitas Katolik Soegijapranata Semarang).

16. Kuncari, E. S., Iskandarsyah, I., \& Praptiwi, P. (2014). Evaluasi, Uji 
Journal of Holistic and Health Sciences Vol.3, No.1, Januari-Juni 2019

Stabilitas Fisik Dan Sineresis Sediaan Gel Yang Mengandung Minoksidil, Apigenin Dan Perasan Herba Seledri
(Apium graveolens L.). Buletin Penelitian Kesehatan, 42(4 Des), 213222. 